\section{Breeding Oil and Table Olives for Mechanical Harvesting in Spain}

\author{
Luis Rallo ${ }^{1}$
}

\begin{abstract}
ADDITIONAL KEY WORDS. mechanization, Olea europaea, olive breeding, 'Sikitita'
Summary. The olive (Olea europaea) and table olive industries worldwide are almost entirely supported by low-density rain-fed orchards planted with local cultivars empirically selected by farmers for centuries. New early and high-bearing plantation systems adapted to mechanical harvesting have been designed and developed during the past 50 years. Only certain traditional cultivars are well suited for these new olive plantations. The new orchards therefore require new cultivars. A long-term effort on the exploration, conservation, and sustainable use of olive genetic resources starting in Spain in $\mathbf{1 9 7 0}$ has been followed by breeding programs developed since the early 1990s by the University of Cordoba, the University of Seville, and the Andalusia Institute for Agricultural, Food and Fisheries Research. We are trying to use crossbreeding to obtain new early bearing cultivars adapted to mechanically harvested orchards. Objectives related to shortening the juvenile period (JP) and developing early tests of selection, early bearing, high cropping, resistance to chief diseases (particularly verticillium wilt caused by Verticillium dabliae), industrial suitability, high oil content, diversity of olive oil composition for oil cultivars, and fruit size and quality for table olive are being pursued. Specific criteria for the adaptation of oil olive and table olive cultivars to mechanical harvesting, such as low-vigor trees with a compact growth habit, the force needed for fruit removal, natural fruit abscission, resistance to bruising, and extending the harvest time in cultivars showing homogeneous ripening are evaluated in the progenies. To date, more than 19,000 seedlings have been initially evaluated, 481 preselections are on intermediate field trials, and 31 advanced selections are being established in a network of field trials. A new protected cultivar Sikitita (Chiquitita in the United States), selected for very-high-density narrow hedgerows, was released in 2008. Recently, a first project on olive genomics is heralding the use of marker-assisted selection in the midterm phase of development. Cultivars adapted to the new mechanical harvest systems will be progressively released in the future.
\end{abstract}

$\mathrm{T}$ raditionally, olives have been cultivated in rain-fed farms with densities of 17-300 trees/ha depending on rainfall. Locally selected cultivars were propagated and planted by farmers, and trees were trained and pruned according to many diverse empirical methods to enhance harvesting by hand or by poling. These plantations were low yielding, late bearing, and long lasting. Certain traditional plantations were irrigated, resulting in marked increases in yield. These irrigated orchards have been planted with 70-100 trees/ha. After World War II, rural migration increased production costs,

Departamento de Agronomía, Campus de Rabanales, Universidad de Córdoba, 14014 Córdoba, Spain

This paper was part of the colloquium "Strategy for Developing Mechanical Harvesting of Horticultural Crops: Simultaneous Short-, Medium-, and Longterm Strategies" held 24 July 2013 at the ASHS Annual Conference, Palm Desert, California, and sponsored by the Production and Harvest Mechanization $(\mathrm{MECH})$ Working Group

The author is in debt with Diego Cabello, Pilar Rallo, and Carlos Trapero for their support in preparing and editing this article.

${ }^{1}$ Corresponding author. E-mail: lrallo@uco.es. and mechanical harvesting became compulsory. Since then, these plantations have begun to be replaced by high-density mechanically harvested orchards. Rain-fed intensive (150-200 trees/ha) and irrigated orchards (250 400 trees/ha), high-density irrigated orchards with wide hedgerows (400800 trees/ha), and superintensive orchards [i.e., very-high-density rain-fed orchards with narrow hedgerows $(800$ 1000 trees/ha) and very-high-density irrigated orchards with narrow hedgerows (>1500 trees/ha)] are increasingly planted for harvest by various mechanical systems (Rallo et al., 2013). Previously, these new orchards have depended on traditional cultivars that were locally selected. However, most of these cultivars display traits that would be undesirable for high-density plantations designed to be mechanically harvested. Therefore, only a few traditional cultivars are currently planted in the new orchards. The need for new specific cultivars for these new plantations has stimulated the development of breeding programs in various countries. This review summarizes the development of the current olive breeding programs in Spain.

\section{Genetic resources}

Exploration, conservation, evaluation, and sustainable use of genetic resources represent a first step in breeding. Systematic exploration of cultivars and centennial olives (i.e., wild and cultivated olives over 100 years old) has been developed in Spain since 1970 (Díez et al., 2011). More than 300 different cultivars (Barranco et al., 2005; Muñoz-Diez, 2008) have been found and have been progressively included in the Olive World Germplasm Bank (OWGB) in Cordoba, Spain.

In 1994, the International Olive Oil Council promoted a network of national banks of germplasm. This network currently includes 968 accessions of supposed autochthonous cultivars from 17 countries. It also includes two international repositories, the OWGB in Cordoba, Spain and another in Marrakech, Morocco. A third is projected in Turkey (Essid, 2010). The joint use of different molecular DNA markers, diversity array technology and simple sequence repeated, and morphological descriptors (Atienza et al., 2013; Trujillo et al., 2014) confirmed most of the previously identified cultivars by morphological markers (Barranco et al., 2005 ) and have shown a high capacity to identify cultivars and determine synonyms, homonyms, and erroneous cultivar names in the OWGB in Cordoba. These problems commonly arise in relationship to the accessions in most olive germplasm collections (Bartolini et al., 2005).

The evaluation of agronomic and oleotechnic traits in two germplasm banks in Spain [Cordoba and Reus (Rallo et al., 2005)] has shown high phenotypic variability for all traits evaluated and provides useful information

\begin{tabular}{llll}
\hline $\begin{array}{l}\text { Units } \\
\begin{array}{l}\text { To convert U.S. to SI, } \\
\text { multiply by }\end{array}\end{array}$ & U.S. unit & SI unit & $\begin{array}{l}\text { To convert SI to U.S., } \\
\text { multiply by }\end{array}$ \\
\hline 0.4047 & acre $(\mathrm{s})$ & ha & 2.4711 \\
0.3048 & $\mathrm{ft}$ & $\mathrm{m}$ & 3.2808
\end{tabular}


for identifying parents for use in the breeding programs.

\section{Crossbreeding programs in Spain}

There are few olive breeding programs worldwide. In Spain, the first breeding program was initiated by 1990. Most of the programs were designed to obtain cultivars for oil and a few for table olives by crossbreeding. To date, programs from only three countries, Israel, Italy, and Spain, have yielded 14 new releases (De la Rosa and León, 2009).

\section{Shortening the JP}

The length of the JP has been the principal obstacle hampering the improvement of fruit trees by crossbreeding. Fruit evaluation in the progeny is initiated when the JP ends. Forcing the growth of the seedlings and the identification of early criteria for selecting early bearing seedlings are known. Early research efforts resulted in very consistent methods for fast, uniform, and high seed germination. Procedures to force growth of seedlings under continuous lighting and fertigation in the greenhouse were also beneficial (Santos-Antunes et al., 2005). This protocol allowed the trees to flower in the following proportions over time: $4 \%$ to $22 \%$ at 26 to 28 months after the sowing of the seeds, $47 \%$ to $65 \%$ at 38 to 40 months after sowing, and 58 to $85 \%$ at 50 to 52 months after sowing. Flowering precocity varied among the progenies corresponding to the parents ('Arbequina' > 'Picual' > 'Frantoio').

More recent results have indicated that this protocol can be further improved. Moreno-Alias et al., (2010) have shown that training the canopy between 1.00 and $1.30 \mathrm{~m}$ high does not delay the time of the first flowering relative to that obtained with the canopy height of $1.60 \mathrm{~m}$ used in the first protocol. These results represent an opportunity for improving the forcing protocol, advancing the first flowering, and simplifying the field management of the progeny, as both the trunk and the canopy are easily managed.

Early selection tests have successfully shortened the JP and eliminated late-flowering seedlings early in their development. The height and the diameter of the seedlings during their first period of growth are good indicators of their potential for early flowering (De la Rosa et al., 2006). The use of these indicators allowed a $40 \%$ reduction of the smaller plants, which had a very low potential for flowering, by the end of their growing period in the greenhouse (P. Rallo et al., 2008a). The relationship among the vigor of the plants in the year previous to the first flowering, the percentage of flowered plants, and the amount of inflorescences and fruit in the seedlings during the first year of flowering appears to represent a general pattern (Moral et al., 2013).

\section{Agronomic evaluation and objectives}

The process of evaluation. There are three main stages for the evaluation of the individuals from any cross progeny. Many nonreplicated seedlings per cross are initially evaluated according to the main objectives of the program. The second stage includes field trials with the above selected seedlings (preselections) for a preliminary evaluation of major agronomic traits such as crop production and vigor that require replication of the preselections. The best ones (advanced selections) are finally included in a network of field trials for evaluating the genotype-by-environment interaction in the expected areas of distribution for these potential new cultivars.

A first tentative protocol for the evaluation of olive progenies in our program is presented in Fig. 1.

EARLY AND HIGH CROP YIELD. New mechanized olive plantations imply high investment, particularly in irrigated orchards. Therefore, they should be able to ensure early bearing and high cropping over the whole life of the orchard, as early and continuous return becomes necessary for the investment to be profitable.

Records of the number of flowering trees and inflorescences per tree from the second to the fourth year after planting the seedlings in the open field has proven to be a useful

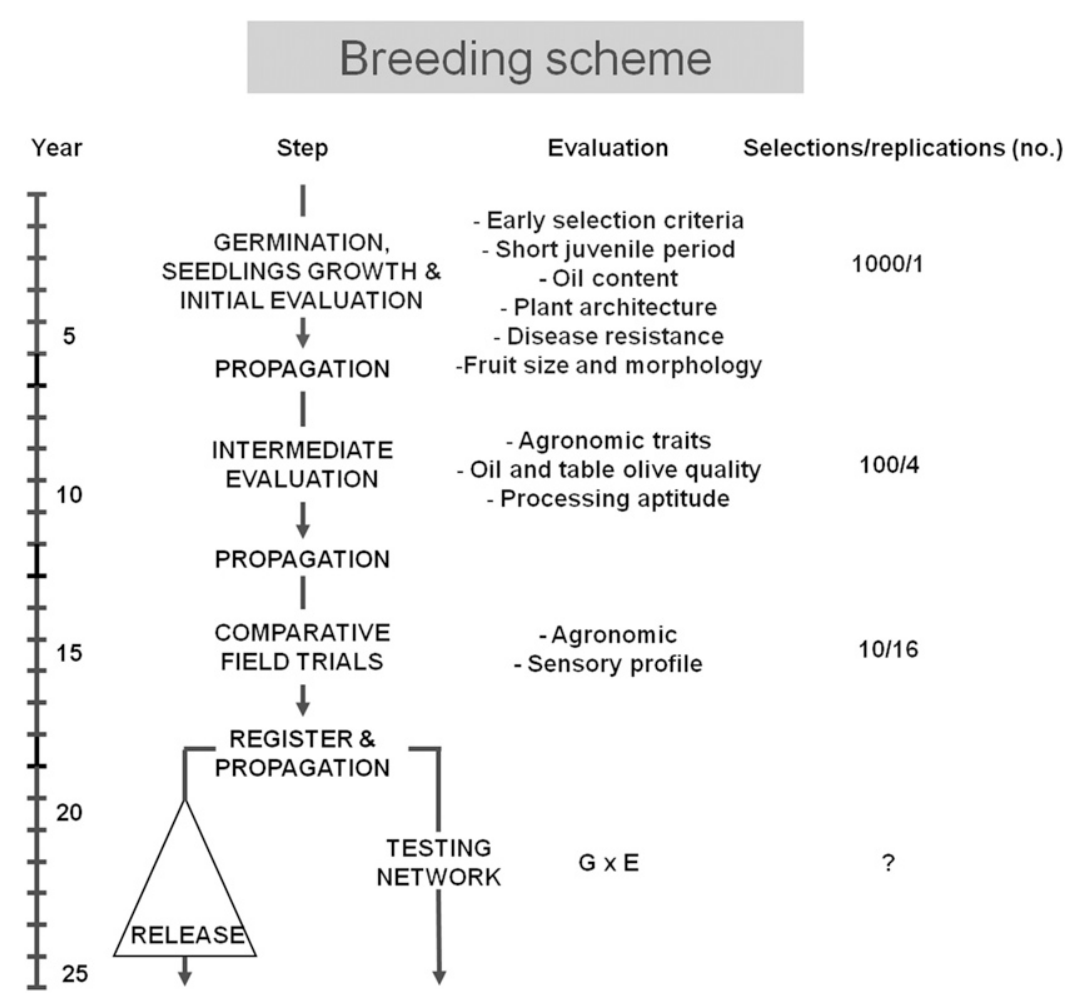

Fig. 1. Breeding scheme for olive programs in Spain. Initial individual seedlings were evaluated according to the main criteria of selection. The seedlings selected, preselections, were then evaluated for main agronomic and oleotechnic traits in intermediate field trials with few replications. Advanced selections were evaluated for many agronomic and oleotechnic traits in comparative field trials in one or more locations. In the later case, the interaction genotype by environment $(\mathbf{G} \times \mathbf{E})$ was evaluated (Rallo et al., 2011a). 
measure for selecting seedlings progenies and evaluating progenitors for early bearing (León et al., 2007; Moral et al., 2013; Santos-Antunes et al., 2005).

High oil content of olives is also critical for oil cultivars. A higher oil content than that of standard high oil-yielding cultivars such as Picual, Frantoio, or Arbequina has proven to be an efficient criterion for selection based on analytical data provided by magnetic nuclear resonance or nearinfrared spectroscopy and on samples representing only 2 years (León et al., 2004).The extractability of oil (i.e., the relationship between the percentage of oil extracted by a standard industrial process and the analyzed oil content) is later evaluated in field trials with advanced selections.

Adaptation to mechanical HARVEST. New high-density olive plantation systems are mechanically harvested with various types of equipment (Rallo et al., 2013). These procedures require specific cultivar traits to ensure harvesting efficiency and the quality of either olive oil or table olives.

Inertia trunk shakers combined with complementary catching frames, inverted-umbrella and "side-by-side" designs, are generally used in intensive plantation systems (Rallo et al., 2013). Traits such as fruit weight (FW), fruit removal force (FRF), and the FRF/FW ratio, natural fruit abscission before harvesting and homogeneous fruit ripening for the selected seedlings once the fruit have reached their oil content threshold are desirable for cultivar suitability in orchards harvested with trunk shakers (Humanes-Guillén, 1976). A high level of variability of these traits among cultivars has been reported in Spain (Kouraba et al., 2004) and among seedlings from breeding progenies that further increase the variability of the parents (De la Rosa et al., 2008).

Damage to the skin, flesh of the olive fruit, or both are determining factors that reduce the quality of the processed fruit in table olives. Several types of damage have been described according to the origin of the damage (e.g., mussel-scale, hail-damage, wrinkled olive). Fruit bruising and blistering are of special relevance. Bruises appear in the fruit as a result of physical impacts during harvesting and subsequent postharvest manipulation, whereas the term "blistering defect" refers to the breakage of the olive skin that eventually occurs during treatment with lye. Resistance/susceptibility to fruit bruising and the suitability for specific processing methods need to be determined (Jiménez, 2009; Jiménez et al., 2011).

Over-the-row harvesters have ensured full fruit removal and olive oil quality (Lavee, 2010; Rallo et al., 2013). However, olive bruising and blistering are reduced, not eliminated, in green table olives (Jiménez, 2012). Resistance to these forms of damage continues to be an objective in the breeding of table olives.

Although reductions in tree size has been proposed to increase harvest efficiency in trunk shaker systems, which implies a tendency to shorten orchard lifespan (Ferguson, 2006), a small and compact growth habit becomes a critical objective in the use of modified grape (Vitis sp.) straddle harvesters for collection in narrow hedgerow plantation. In this context, preliminary results have shown the influence of the genitors on the vigor and growth habit of the seedlings at the end of the initial step of evaluation in the field (Rallo et al., 2011a).

A review on the works on genetic resources and breeding in olive with reference to quality has been published (Rallo et al., 2011b).

RESISTANCE TO FUNGAL DISEASES. The new mechanized and irrigated high-density plantation systems have been related to a higher incidence of certain diseases than that occurring in standard rain-fed orchards. These included airborne defoliating fungal diseases and verticillium wilt of olives (Rallo et al., 2013). Tests for evaluating resistance to peacock spot (Fusicladium oleaginum), cercosporiosis (Pseudocercospora cladosporioides), and anthracnose (Colletotrichum sp.), the three principal airborne defoliating diseases, in cultivars of the OWGB in Cordoba and in progenies and preselections of our program have shown high variability among descendants from the same cross. For peacock spot, with resistant cultivars such as Frantoio and Lechín de Sevilla used as parents, the progenies showed a high percentage of highly resistant or resistant seedlings, although several preselections for early bearing and high oil content from crosses between two susceptible cultivars, Picual and Arbequina, were also moderately resistant (Moral et al., 2005).

For anthracnose, most of the major Spanish cultivars evaluated were susceptible or highly susceptible. Only 'Empeltre' and 'Picual' showed a degree of resistance, with 'Arbequina' highly susceptible and 'Frantoio' resistant (Moral and Trapero, 2009). Several of the preselections for early bearing and high oil content from the crosses among 'Arbequina', 'Frantoio', and 'Picual' were significantly more resistant than 'Arbequina', particularly in the case of genotypes from the cross between 'Frantoio' and 'Picual' (Moral et al., 2006).

None of the preselections from the crosses among Arbequina', 'Frantoio', and 'Picual' were resistant to cercosporiose. This lack of resistance is most likely due to the susceptibility of the three genitors to the pathogen (Moral et al., 2005). New resistant genitors, such as 'Koroneiki', are being used in new crosses and the resultant progenies are under evaluation.

A two-step protocol for evaluating cultivars and seedling genotypes for resistance to verticillium wilt is currently on course in a controlled environment and in highly infested field plots (Trapero et al., 2011 , 2013a). The first step is the screening of 40-day-old olive seedlings via root-dipping inoculation with a highly virulent $V$. dabliae isolate (V117) in a controlled environment. This screening program discriminates between resistant and susceptible seedlings in a short period of time (Trapero et al., 2013a). This method has allowed the screening of more than 8000 seedlings, of which $\approx 600$ were resistant. The second step is a field evaluation in plots infested with the highly virulent $V$. dabliae isolate. Eleven cultivars, including resistant and susceptible ones (Trapero et al., 2013b), have been tested in these field trials with several replications. Almost all trees of 'Bodoquera', 'Cornicabra', 'Manzanilla de Sevilla', and 'Picual' were killed. In contrast, 'Empeltre', 'Changlot Real', and 'Frantoio' showed a high level of disease resistance (Trapero et al., 2013 b) after 20 to 22 months of planting. Currently, this protocol of field evaluation is in progress for the seedlings selected in the previous dip inoculation test (C. Trapero, personal communication). In summary, this protocol may, after a short time ( 2 to 
3 years), yield preselections resistant to verticillium wilt and produce advances in their agronomic preliminary evaluation, thus reducing the time required for the initial and the intermediate evaluation stages (Fig. 1).

QuALITY OF OIL AND TABLE OLIVES. Fatty acids (León et al., 2004, 2008) and phenolic profiles (El Riachy et al., 2012a, 2012b) have been evaluated in progenies and advanced selections from various crosses among 'Arbequina', 'Frantoio', and 'Picual'. The composition of both fatty acid and phenolic compounds differs among these progenies and selections. The following common conclusions have been obtained for both oil components: 1) any cross yields a higher range of variability for any compound than the parents, either in progenies or advanced selections and 2) there is a highly significant correlation among the values of any individual in different stages of evaluation (initial progeny and advanced selections).

In contrast, the evaluation of these compounds has shown the following differences: 1) selection for fatty acid composition can be performed efficiently by considering only a single year of evaluation at the seedling stage, 2) there are clear differences between years in the composition of the phenolic compounds, and 3) sampling at early fruit harvest is recommended for better comparisons of phenolic compounds among seedlings due to the differential changes in the phenolic profile with the progress of fruit ripening. These results suggest that new olive cultivars with a composition of fatty acids and phenolics that satisfies consumer and market demands could be obtained through crossbreeding in the future.

Similarly, in breeding for table olives, fruit morphological traits such as fruit size and shape, stone size and shape, flesh:pit ratio, and flesh texture have been evaluated (P. Rallo et al., $2008 \mathrm{~b}, 2012)$. There is almost no information available on the composition of the fruit in the progenies in table olive breeding programs. Nevertheless, the influence of certain compounds, such as polyphenols, triterpenic acids, and sugars, on the quality of processed table olives is making breeders consider the possible inclusion of these traits in the evaluation of the progenies' raw fruit
(Medina et al., 2012; P. Rallo et al., 2008 b). Finally, protocols to evaluate several other interesting traits, such as resistance/susceptibility to fruit bruising or suitability for specific processing methods, are being established (Jiménez, 2009, 2012; Jiménez et al., 2011).

\section{New materials \\ Current state}

The current state of the seedlings evaluated and in evaluation (Table 1 ) summarizes the advances achieved by the breeding programs. All breeding programs share common objectives (high and early crops, high-density plantations, and mechanical harvesting). Oil content is essential for oil cultivars, and the fruit size and shape and the quality of the processed olives are essential for table cultivars. Resistance to $V$. dabliae is the first criterion for selection in a new program. The current data indicate the potential of these breeding programs.

We are currently propagating eight advanced selections for narrow hedgerow orchards to develop an experimental network in various countries according to a public-private agreement for collaboration.

\section{'Sikitita'}

A new cultivar adapted to highdensity hedgerow orchards has been selected and protected; it was then released in 2008 (L. Rallo et al., 2008). The first commercial orchards of this cultivar were planted in 2009 . They produced their first full crop in 2012-13 (Fig. 2). The traits of this new cultivar are presented on an updated web page (Pomología Sociedad Limitada, 2013) with available and useful information for the scientific community and for the olive industry.

\section{The future}

The changes occurring in olive plantations over the past 50 years will certainly continue in the future. The best-suited cultivars for these new orchards, including cultivars from Spain and several from abroad, had been planted by the mid-1980s as the nursery industry developed.

The continuous efforts conducted in Spain since the 1970s have allowed cultivars to be catalogued and to be conserved in germplasm banks, with true-to-type accessions identified with morphological and molecular markers. Agronomic evaluation in germplasm banks and in field trials had been initiated by the mid-1970s. The new olive breeding programs led to a continuous process of phenotyping in germplasm banks, progenies, and new selections. The recent projects in olive genomics in various countries will certainly increase the current knowledge of olive genetics

Table 1. Approximate number of olive initial seedlings, preselections and advanced selections in the olive breeding programs of Spain.

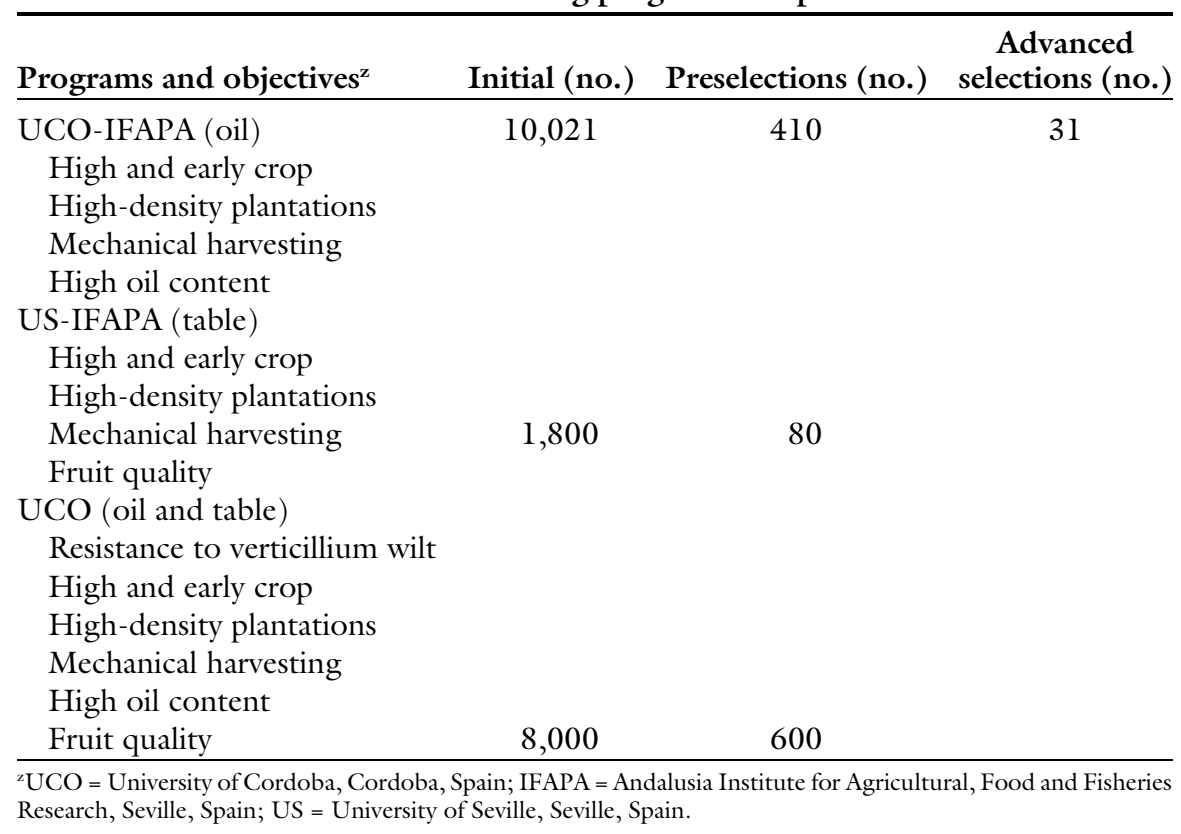




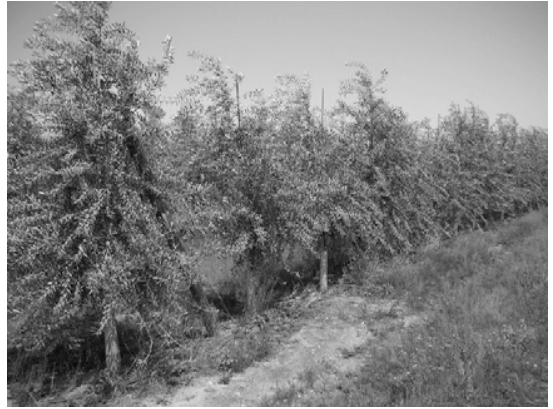

Fig. 2. High-density irrigated hedgerow orchard of. 'Sikitita' olive planted at $4.0 \times 1.5 \mathrm{~m}(13.12 \times 4.92 \mathrm{ft})$ in Huelva, Spain. Flowering trees 29 months after plantation.

and provide useful tools for breeding in the midterm. The static picture of the cultivar map in all traditional olive-growing countries will be progressively replaced by newly bred cultivars adapted to the new growing areas and plantation systems.

\section{Literature cited}

Atienza, S.G., R. De la Rosa, M.C. Domínguez-García, A. Martín, A. Kilian, and A. Belaj. 2013. Use of DArT markers as a means of better management of the diversity of olive cultivars. Food Res. Intl. 54:2045-2053.

Barranco, D. and I. Trujillo. 2005. Libro I. Elaiografía Hispánica, p. 45-229. In: L. Rallo, D. Barranco, J.M. Caballero, C. Del Río, A. Martín, J. Tous, and I. Trujillo (eds.). Variedades de olivo en España. Junta de Andalucía, MAPA y Ediciones Mundi-Prensa, Madrid, Spain.

Bartolini, G., G. Prevost, C. Messeri, and C. Carignani. 2005. Olive germplasm: Cultivars and world-wide collections. 25 Nov. 2013. <http://apps3.fao.org/ wiews/olive/oliv.jsp >.

De la Rosa, R., A.I. Kiran, D. Barranco, and L. León. 2006. Seedling vigor as a preselection criterion for short juvenile period in olive breeding. Austral. J. Agr. Res. 57:477-481

De la Rosa, R. and L. León. 2009. Nuevas variedades y perspectivas futuras de la mejora varietal. Vida Rural 293:41-44.

De la Rosa, R., L. León, I. Moreno, D. Barranco, and L. Rallo. 2008. Ripening time and fruit characteristics of advanced olive selections for oil production. Austral. J. Agr. Res. 59:46-51.

Díez, C.M., I. Trujillo, E. Barrio, A. Belaj, D. Barranco, and L. Rallo. 2011. Centennial olive trees as a reservoir of genetic diversity. Ann. Bot. (Lond.) 108:797-807.
El Riachy, M., F. Priego-Capote, L. León, M. Dolores Luque-de-Castro, and L. Rallo. 2012a. Virgin olive oil phenolic profile and variability in progenies from olive crosses. J. Sci. Food Agr. 92:25242533 .

El Riachy, M., F. Priego-Capote, L. Rallo, M.D. Luque-de-Castro, and L. León. 2012 b. Phenolic composition of virgin olive oils from cross breeding segregating populations. Eur. J. Lipid Sci. Technol. 114:542-551.

Essid, H. 2010. Olive genetic resources: A legacy of biodiversity. 28th Intl. Hort. Congr. Abstr. 1:307. (abstr.).

Ferguson, L. 2006. Trends in olive harvesting. Grasas y Aceites 57:9-15.

Humanes-Guillén, J. 1976. Recolección mecanizada de la aceituna, p. 293-316. In: J.M. Phillippe, J. Humanes-Guillén, G. Piquer, and R. Téllez-Molina. (eds.). Olivicultura moderna. FAO, INIA, and Editorial Agrícola Española, Madrid, Spain.

Jiménez, R. 2009. Evaluación de la aptitud de nuevos genotipos de olivo para su elaboración como aceituna de mesa. Univ. Cádiz, Cádiz, Spain, MSc Diss.

Jiménez, R. 2012. Puesta a punto de métodos de evaluación de parámetros de calidad de aceituna de mesa en un programa de mejora genética. Univ. Seville, Seville, Spain, PhD Diss.

Jiménez, R., P. Rallo, M.P. Suárez, A. Morales-Sillero, L. Casanova, and $\mathrm{H}$. Rapoport. 2011. Fruit bruising in table olives. Acta Hort. 924:419-424.

Kouraba, K., J. Gil-Ribes, G.L. BlancoRoldán, M.A. De Jaime, and D. Barranco. 2004. Suitability of olive varieties for mechanical harvesting. Olivae 101:38-43.

Lavee, S. 2010. Integrated mechanical, chemical and horticultural methodologies for harvesting of oil olives and the potential interaction with different growing systems. A general review. Adv. Hort. Sci. 24:5-15.

León, L., R. De la Rosa, D. Barranco, and L. Rallo. 2007. Breeding for early bearing in olive. HortScience 42:499-502.

León, L., R. De la Rosa, A. Gracia, D. Barranco, and L. Rallo. 2008. Fatty acid composition of advanced olive selections obtained by crossbreeding. J. Sci. Food Agr. 88:1921-1926.

León, L., L.M. Martín, and L. Rallo. 2004. Phenotypic correlations among agronomic traits in olive progenies. J. Amer. Soc. Hort. Sci. 129:271-276.

Medina, E., A. Morales-Sillero, E.M Ramírez, P. Rallo, M. Brenes, and C.
Romero. 2012. New genotypes of table olives: Profile of bioactive compounds. Intl. J. Food Sci. Technol. 47:23342341 .

Moral, J., M. Alsalimiya, C. Muñoz-Diez, L. León, R. de la Rosa, and A. Trapero. 2006. Evaluación de preselecciones de olivo por su resistencia a repilo y antracnosis. Actas de Horticultura 45:177-178.

Moral, J., A. Ávila, L.M. López-Doncel, M. Alsalimiya, R. Oliveira, F. Gutiérrez, N. Navarro, K. Bouhmidi, A. Benali, L.F. Roca, and A. Trapero. 2005. Resistencia a los repilos de distintas variedades de olivo. Vida Rural 208:34-40.

Moral, J., C.M. Díez, L. León, R. de la Rosa, F. Santos-Antunes, D. Barranco, and L. Rallo. 2013. Female genitor effect on the juvenile period of olive seedlings. Sci. Hort. 156:99-105.

Moral, J. and A. Trapero. 2009. Assessing the susceptibility of olive cultivars to anthracnose caused by Colletotrichum acutatum. Plant Dis. 93:1028-1036.

Moreno-Alias, I., H.F. Rapoport, L. León, and R. De la Rosa. 2010. Olive seedling first-flowering position and management. Sci. Hort. 124:74-77.

Muñoz-Diez, C. 2008. Prospección, diversidad genética y conservación de ejemplares monumentales y poblaciones silvestres de olivo (Olea europaea L.). Univ. Cordoba, Cordoba, Spain, PhD Diss.

Pomología Sociedad Limitada. 2013. Sikitita. 25 Nov. 2013. <http://www. sikitita.es>.

Rallo, L., D. Barranco, J.M. Caballero, C. Del Río, A. Martín, J. Tous, and I. Trujillo (eds.). 2005. Variedades de olivo en España. Junta de Andalucía, MAPA and Ediciones Mundi-Prensa, Madrid, Spain.

Rallo, L., D. Barranco, S. Castro-García, D.J. Connor, M. Gómez del Campo, and P. Rallo. 2013. High-density olive plantations. Hort. Rev. 41:303-382.

Rallo, L., D. Barranco, R. De la Rosa, and L. León. 2008. 'Chiquitita' olive. HortScience 43:529-531.

Rallo, L., D. Barranco, R. De La Rosa, and L. León. $201 \mathrm{l}$ a. Advances in the joint UCO-IFAPA olive breeding program (JOBP). Acta Hort. 924:283-290.

Rallo, L., M. El Riachy, and P. Rallo. $2011 \mathrm{~b}$. The time and place for fruit quality in olive breeding. p. 323-348. In: M.A. Jenks, and P.J. Bebeli (eds.). Breeding for fruit quality. Wiley, Hoboken, NJ

Rallo, P., R. Jiménez, A. Morales, L. Casanova, and M.P. Suárez. 2012. Evaluation of 


\section{Colloquium}

table-olive quality parameters in progenies obtained by cross-breeding. Acta Hort. 949:527-531.

Rallo, P., R. Jimenez, J. Ordovás, and M.P. Suarez. 2008a. Possible early selection of short juvenile period olive plants based on seedling traits. Austral. J. Agr. Res. 59:933-940.

Rallo, P., E. Toledo, M.P. Suárez, R. Jiménez, L. Casanova, and A. MoralesSillero. 2008b. Variabilidad en los contenidos de azúcares y polifenoles en pulpa verde de aceituna: Evaluación de progenies. Actas de Horticultura 51: $351-352$.
Santos-Antunes, F., L. León, R. De la Rosa, J. Alvarado, A. Mohedo, I. Trujillo, and L. Rallo. 2005. The length of the juvenile period in olive as influenced by vigor of the seedlings and the precocity of the parents. HortScience 40:1213-1215.

Trapero, C., C. Muñoz-Díez, L. Rallo, F.J. López-Escudero, and D. Barranco. 2011. Screening olive progenies for resistance to Verticillium dabliae. Acta Hort. 924:137-140.

Trapero, C., C.M. Díez, L. Rallo, D. Barranco, and F.J. López-Escudero. 2013a. Effective inoculation methods to screen for resistance to verticillium wilt in olive. Sci. Hort. 162:252-259.

Trapero, C., N. Serrano, O. Arquero, A. Trapero, and F.J. López-Escudero. 2013b. Field resistance to verticillium wilt in selected olive cultivars grown in two naturally infested soils. Plant Dis. 97:668-674.

Trujillo, I., M.A. Ojeda, N.M. Urdiroz, D. Potter, D. Barranco, L. Rallo, and C.M. Diez. 2014. Identification of the worldwide olive germplasm bank of Córdoba (Spain) using SSR and morphological markers. Tree Genet. Genomes 10:141-155. 